\title{
The Need to Revitalize Agricultural Productivity Research for Food Security: a Min-Review
}

\author{
Birhan Sisay Demissie* \\ Institute of Economic Research, Bahir Dar University, Ethiopia
}

Submission: December 25, 2017; Published: March 26, 2018

"Corresponding author: Birhan Sisay Demissie, Institute of Economic Research, Bahir Dar University, Ethiopia, Email: hiwete2000@gmail.com

\section{Mini-Review}

Since the early 1970's, the term food security arose as a concept of food supply. The global food supply shortages at the time led to concerns that would threaten political stability [1]. And food availability was a fundamental component of food security. The most robust definition of food security is the 1996 World Food Summit:“Food security, at the individual, household, national, regional and global levels [is achieved] when all people, at all times, have physical and economic access to sufficient, safe and nutritious food to meet their dietary needs and food preferences for an active and healthy life" [2]. This definition incorporates the availability, access, and utilization domains of food security and is widely used today.

Despite the recognition of the access and utilization dimensions, food availability remains a fundamental component of food security for the increasing world population. Over the past 50 years, the world's population more than doubled and a significant number of people still live a hand-to-mouth existence in developing world [3,4]. In order to feed this increasing population, increasing the production of food matters most. The agricultural sector is the primary source of food production. In 2010 , about 40 percent of the world working population earn their livelihoods from agriculture. While only 3.2 percent of the working population in high-income countries was employed in agriculture, about 64.5 percent of those in low-income countries [5]. Land used in agriculture worldwide increased by much less than global population, such that in 2010 , agriculture had to feed 1.41 persons per hectare compared with just under 1 person in 1800 [5]. Despite double world population growth over the past 50 years (1961-2010), the global food supply grew even faster averting the Malthusian theory . From 1961 to 2010, real output from agriculture grew by 2.7 percent per year, andagricultural output per person grew by 60.6 percent-from $\$ 209$ per person in 1961 (2004-06 international prices) to $\$ 336$ per person in 2010
[6]. As a result, real prices of cereals fell by 60 percent between 1961 and $2010[3,4]$.

The increase in agricultural productivity is attributed to the use of modern inputs, particularly machinery, fertilizers, and irrigation combined with improved genetic material and methods of production increasingly derived from organized scientific agricultural research [7]. Many studies have found that high rates of return are related to high investments in agricultural productivity researches [8]. The major benefits of high agricultural productivity are enhanced farm incomes, lower costs of food production, reduced stress on the natural resource base, and the release of resources for other uses $[7,8]$. However, the recent trends are less salutary [4]. Since 1990, the growth rates of agricultural productivity have systematically slowed for most countries and for the world as a whole [6]. These slowdown productivity along with other factors is reflected in overall food items price rise since 2000 [3,4]. Such slowdown of agricultural productivity is related to the low rates of investment in agricultural research in many of the developed and developing countries [4].

Therefore, in order to meet the increasing food demands of the growing world population, significant growth in agricultural production will be necessary for the coming 50 years [9]. Given a shrinking of the scope for expanding the agricultural use of land and water, much of the growth in production will have to come from increased productivity. Agricultural productivity in the future require taking into account the emerging challenges of climate change and the attendant implications for changing abiotic (i.e., drought, temperature, and so on) and biotic (i.e., pest and disease) stresses on agricultural plants and animals [9]. Hence, revitalization of agricultural production research for food security (food availability) is important in the decades to come.

${ }^{1}$ In the $18^{\text {th }}$ century, Thomas Malthus proposed that when human populations grow faster than the capacity of the world to feed them, leading to widespread famine is called the Malthusian theory. 
Alston \& Pardey [4] explore three competing ideas of agricultural productivity research revitalization. The first view suggests the need to directly revitalize and refocus on agricultural research to enhance farm productivity growth and make food more abundant and cheaper, thereby addressing problems of poverty and food security that are foreseen through to 2050 [10]. The second view suggests the need to ramp up research on fruits and vegetables at the expense of research on cereals and livestock products, as a way of improving nutritional outcomes. The third view proposes that agricultural productivity research should emphasize other dimensions of nutrition, such as developing staple foods that are richer in specific micronutrients. As conclusion, agricultural productivity research should be revitalized to meet the food demands of the increasing world population in the decades ahead.

\section{References}

1. Jones AD, Ngure FM, Pelto G, Young SR (2013) What Are We Assessing When We Measure Food Security? A Compendium and Review of Current Metrics. Advances in Nutrition 4(5): 481-505.

2. FAO (1996) Rome declaration on world food security and world food summit plan of action. Food and Agriculture Organization of the United Nations, USA.
3. Alston JM, Beddow JM, Pardey PG (2009) Agricultural Research, Productivity and Food Prices in the Long Run. Science 325(4): 1209-1210.

4. Alston JM, Pardey PG (2015) Agricultural R\&D, Food Prices, Poverty, and Malnutrition Redux. In: David E Sahn (Ed.), The Fight Against Hunger and Malnutrition- The Role of Food, Agriculture, and Targeted Policies. Oxford University Press, New York, USA.

5. FAO (2013) FAOSTAT database. Food and Agriculture Organization of the United Nations, USA.

6. Alston JM, Pardey PG (2014) Agriculture in the Global Economy. Journal of Economic Perspectives 28(1): 121-146.

7. Pardey PG, Alston JM, Ruttan VW (2010) The Economics of Innovation and Technical Change in Agriculture. In: Hall BH, N. Rosenberg N (Ed.), Handbook of Economics of Innovation. Elsevier, Amsterdam, USA, pp. 939-984.

8. Hurley TM, Rao X, Pardey PG (2014) Re-examining the Reported Rates of Return to Food and Agricultural Research and Development. American Journal of Agricultural Economics 96(5): 1492-1504.

9. Pardey PG, Beddow JM, Hurley TM, Beatty TK, Eidman VR (2014) A Bounds Analysis of World Food Futures: Global Agriculture Through 2050. Australian Journal of Agricultural and Resource Economics 58(4): 571-589.

10. Ravallion M (2013) How Long Will it Take to Lift One Billion People Out of Poverty? World Bank Research 28(2): 139-158.

\section{Your next submission with Juniper Publishers} will reach you the below assets

- Quality Editorial service

- Swift Peer Review

- Reprints availability

- E-prints Service

- Manuscript Podcast for convenient understanding

- Global attainment for your research

- Manuscript accessibility in different formats ( Pdf, E-pub, Full Text, Audio)

- Unceasing customer service

Track the below URL for one-step submission https://juniperpublishers.com/online-submission.php 